\title{
Remote Oncology Care: Review of Current Technology and Future Directions
}

\author{
Bradley A. McGregor ${ }^{1}$, Gregory A. Vidal ${ }^{2}$, Sumit A. Shah ${ }^{3}$, James D. Mitchell ${ }^{4}$, Andrew E. Hendifar ${ }^{5}$ \\ 1. Oncology, Dana-Farber Cancer Institute, Boston, USA 2. Oncology, West Cancer Center and Research Institute and \\ the University of Tennessee Health Science Center, Memphis, USA 3. Oncology, Stanford University School of \\ Medicine, Palo Alto, USA 4. Radiation Oncology, Northbay Healthcare, Vacaville, USA 5. Oncology, Cedars-Sinai \\ Medical Center, Los Angeles, USA
}

Corresponding author: James D. Mitchell, james@oncodisc.com

\begin{abstract}
Cancer patients frequently develop tumor and treatment-related complications, leading to diminished quality of life, shortened survival, and overutilization of emergency department and hospital services. Outpatient oncology treatment has potential to leave cancer patients unmonitored for long periods while at risk of clinical deterioration which has been exaggerated during the COVID19 pandemic. Visits to cancer clinics and hospitals risk exposing immunocompromised patients to infectious complications. Remote patient reported outcomes monitoring systems have been developed for use in cancer treatment, showing benefits in economic and survival outcomes. While advanced devices such as pulmonary artery pressure monitors and implantable loop recorders have proven benefits in cardiovascular care, similar options do not exist for oncology. Here we review the current literature around remote patient monitoring in cancer care and propose the use of reliable devices for capturing and reporting patient symptoms and physiology.
\end{abstract}

Categories: Radiation Oncology, Oncology, Healthcare Technology

Keywords: patient reported outcomes, remote monitoring, oncology, implantable medical device, pro, rpm

\section{Introduction And Background}

Cancer is a leading cause of morbidity and mortality in the United States, with over 1.8 million new cancer diagnoses and more than 600,000 cancer deaths estimated for 2020 [1]. Furthermore, cancer care significantly impacts the overall healthcare system through high rates of emergency department utilization, hospital admission, and costly treatments whose toxicities have potential to diminish quality of life [2-4].

Received 07/18/2020 Review began 07/21/2020 Review ended 08/20/2020 Published 08/31/2020

○) Copyright 2020 McGregor et al. This is an open access article distributed under the terms of the Creative Commons Attribution License CC-BY 4.0., which permits unrestricted use, distribution, and reproduction in any medium, provided the original author and source are credited.
Cancer patients frequently experience local and systemic symptoms causally related to their malignancy. Local symptoms are due to direct complications of the primary tumor or metastases and can include pain, neurological deficits, respiratory symptoms (cough, shortness of breath, hemoptysis) and obstruction (bowel, biliary, airway). Systemic complications include cachexia, paraneoplastic syndromes, electrolyte abnormalities, metabolic alterations, and hematologic changes. These symptoms are a frequent cause of hospitalization. In a series reported by Numico et al., $74 \%$ of hospitalizations of cancer patients were for conditions related to tumor involvement, with a minority for workup or treatment-related complications. The most common symptoms at the time of admission were dyspnea, pain, neurological (not specified by authors), fever, and gastrointestinal (vomiting, jaundice) [5]. Identifying and addressing cancer symptom burden prior to the need for admission is recognized as a critical need and has led to increased utilization of patient-reported outcome (PRO) tools discussed in detail below.

In addition to tumor-related morbidity, cancer patients suffer treatment-related complications. Given the myelosuppressive nature of radiation and chemotherapy, anemia, neutropenia, and thrombocytopenia with associated malaise, infection, and bleeding can occur. One of the most serious complications, neutropenic sepsis, is associated with up to $50 \%$ mortality rate, average hospital cost of over $\$ 49,000$, and total expenditures of $\$ 1.1$ billion per year in the US [6,7]. Less severe though far more prevalent toxicities such as nausea, vomiting, and diarrhea can have a large negative impact leading to volume depletion, metabolic and electrolyte imbalances and renal failure. Newer immunotherapies are associated with immune-related adverse events with unpredictable timing and vagueness of symptoms, making identification and management especially challenging [2-4].

Modern technology can increase patients' connectivity to the healthcare system through mobile communications and remote physiologic monitoring [8]. Monitoring systems have been used most extensively for cardiovascular diseases such as congestive heart failure (CHF) and arrhythmia detection. For patients that require long-term monitoring for either of these, implantable devices like CardioMEMS ${ }^{\mathrm{TM}}$ and implantable loop recorders (ILR) have been shown to decrease rates of hospitalization, improve arrhythmia detection, and lower costs compared with usual care $[9,10]$. In oncology, while implantable devices are not available, studies have shown that monitoring patient-reported outcomes reduces visits to the emergency department, decreases follow-up costs and improves overall survival [11-14]. 
Since the outbreak of a novel SARS-CoV-2 in 2019 (Covid-19), the term "social distancing" has entered the common lexicon. However, social distancing has been a mainstay of oncologic care for decades as immunosuppressed cancer patients take precautions to minimize risk of infections. Patients are instructed to eliminate interactions with sick contacts and avoid large gatherings. Yet at the same time, patients attend frequent visits to outpatient cancer centers for clinical evaluations. For a neutropenic patient, each visit poses a risk for infectious exposure. The latter is further magnified since the onset of the Covid-19 pandemic. As a result, the Centers for Medicare and Medicaid services (CMS) has broadened its coverage of Telehealth services under the 1135 waiver authority and coronavirus preparedness and Response Supplementation Appropriation Act, which has significantly expanded the volume of patients receiving care via telemedicine [15]. Though this has reduced oncology patients' infectious exposure, it has created the dilemma for laboratory and vital sign monitoring for patients at risk for drug-induced toxicities. Tools that facilitate social distancing while maintaining connectivity to the healthcare system and providing objective data for ongoing management are urgently needed $[16,17]$.

\section{Review}

\section{Monitoring systems for oncology}

Representative prospective randomized studies of remote and/or electronic PRO in cancer care are summarized in Table 1. PRO-CTCAE ${ }^{\mathrm{TM}}$ (Patient-Reported Outcomes version of the Common Toxicity Criteria for Adverse Events) is a validated tool used to monitor and report toxicities related to cancer treatment in clinical trials. Basch et al. reported results from a prospective randomized study from Memorial Sloan Kettering Cancer Center evaluating the efficacy of an online symptom reporting tool [13,14]. A total of 766 patients with advanced solid tumors undergoing systemic cytotoxic chemotherapy were randomized to either an online symptom reporting platform or usual care. In the experimental arm, patients received weekly email prompts to report on 12 common treatment-related toxicities through a web-based portal called Symptom Tracking and Reporting (STAR). A severe or marked change in symptom reporting prompted an email alert to an oncology nurse; summary reports were made available to the treating physician at the time of clinical visits. Over the course of the study, the STAR platform was associated with an improvement in health-related quality of life scores ( $34 \%$ vs $18 \%, p<0.001$ ), with fewer visits to the emergency department $(34 \%$ vs $41 \%, p=0.02)$ compared to standard of care. Median overall survival was also $20 \%$ longer in the PRO arm (31.2 months vs 26.0 months, $\mathrm{p}=0.04$ ). The authors proposed that the mechanism of improved survival was related to early interventions including active remote symptom management, supportive medications, chemotherapy dose modifications, and referrals for specialty consultation that prevented downstream consequences. Additionally, the PRO group was able to tolerate continuation of chemotherapy for a longer duration $(8.2$ months vs 6.3 months, $\mathrm{p}=0.002)$.

\begin{tabular}{|c|c|c|c|}
\hline Patients & PRO Intervention & Endpoints & Key Findings \\
\hline \multirow[t]{5}{*}{$\begin{array}{l}766 \text { adult patients with } \\
\text { metastatic breast, } \\
\text { gynecologic, } \\
\text { genitourinary or lung } \\
\text { cancers undergoing } \\
\text { chemotherapy }[13,14]\end{array}$} & $\begin{array}{l}\text { Self-reporting via Symptom Tracking and } \\
\text { Reporting (STAR) on } 12 \text { common } \\
\text { chemotherapy-related symptoms: appetite } \\
\text { loss, constipation, cough, diarrhea, } \\
\text { dyspnea, dysuria, fatigue, hot flashes, } \\
\text { nausea, pain, neuropathy, and vomiting }\end{array}$ & $\begin{array}{l}\text { Change in } \\
\text { health-related } \\
\text { quality of life } \\
\text { (HRQL) at six } \\
\text { months }\end{array}$ & $\begin{array}{l}\text { HRQL at six months improved in more patients in } \\
\text { the PRO arm than the usual care arm ( } 34 \% \text { vs. } 18 \%) \\
\text { and worsened in fewer patients in the PRO arm } \\
(38 \% \text { vs. } 53 \% ; \mathrm{P}<0.001)\end{array}$ \\
\hline & & $\begin{array}{l}\text { Survival at one } \\
\text { year }\end{array}$ & $\begin{array}{l}\text { Median overall survival was prolonged in PRO } \\
\text { patients ( } 31.2 \text { vs. } 26.0 \text { months; } P=0.03 \text { ) }\end{array}$ \\
\hline & & $\begin{array}{l}\text { Adherence } \\
\text { with STAR } \\
\text { self-reporting }\end{array}$ & $\begin{array}{l}73 \% \text { of patients in the PRO arm completed a self- } \\
\text { assessment at any given clinic visit }\end{array}$ \\
\hline & & & $\begin{array}{l}\text { Fewer patients required emergency department } \\
\text { visits in the } \mathrm{PRO} \text { group ( } 34 \% \text { vs. } 41 \% ; \mathrm{P}=0.02)\end{array}$ \\
\hline & & & $\begin{array}{l}\text { Patients in the PRO arm received systemic } \\
\text { chemotherapy for a longer duration than in the } \\
\text { usual care arm ( } 8.2 \text { months vs. } 6.3 \text { months; } P= \\
0.002 \text { ) }\end{array}$ \\
\hline $\begin{array}{l}133 \text { adult patients with } \\
\text { Stage IIATXN1 to Stage IV }\end{array}$ & & & \\
\hline $\begin{array}{l}\text { TxNxM+ non-small cell or } \\
\text { small cell lung cancer } \\
\text { with non-progressive } \\
\text { disease after therapy }\end{array}$ & $\begin{array}{l}\text { Self-reporting via e-follow-up application } \\
\text { (eFAP) in which } 12 \text { symptoms are reported } \\
\text { weekly }\end{array}$ & $\begin{array}{l}\text { Overall } \\
\text { survival }\end{array}$ & $\begin{array}{l}\text { Median survival was longer in the } \mathrm{PRO} \text { group }(22.5 \\
\text { months vs. } 14.9 \text { months, } \mathrm{HR} 0.59[95 \% \mathrm{Cl}, 0.37- \\
0.96] ; \mathrm{P}=.03 \text { ) }\end{array}$ \\
\hline
\end{tabular}




\section{Cureus}

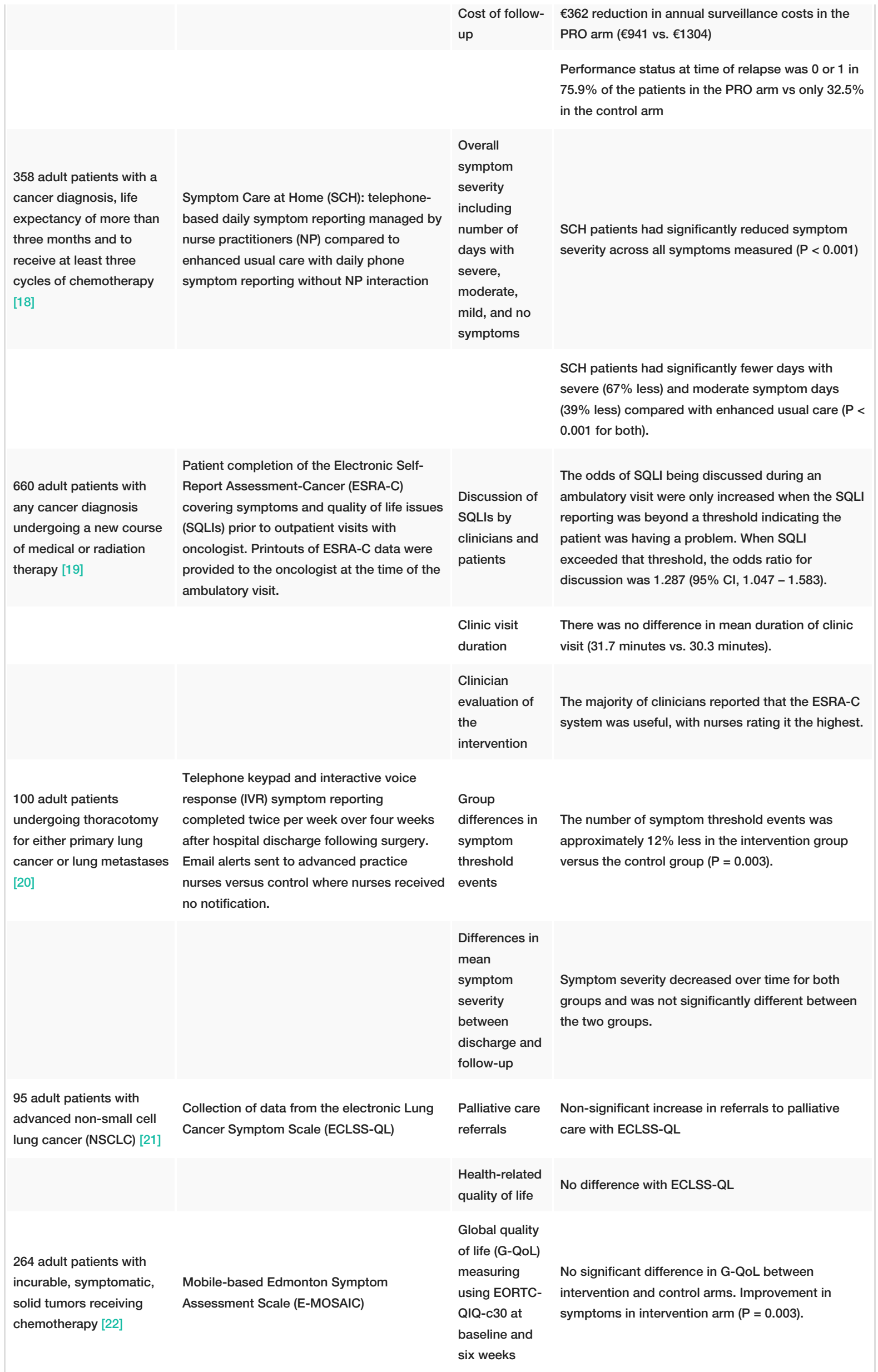




\section{Cureus}

752 adult ambulatory patients with any cancer diagnosis starting a new treatment regimen [23]

325 adult patients undergoing therapy for breast or prostate cancer [24]

139 adult breast cancer patients undergoing chemotherapy [25]

261 adult patients with primary or metastatic hepatobiliary tumors treated with chemoembolization, radioembolization, or surgical resection and 179 family caregivers [26]
Electronic symptom and quality of life (SxQOL) screening tool with or without targeted education, communication coaching, and ability to track data over time

WebChoice: an internet-based application for patients to monitor symptoms, receive information on self-care, communicate with nurses, and connect with other patients for support

Mobile application with questionnaire regarding ECOG performance status and 30 preselected adverse events with severity rating

\author{
Symptom \\ distress as \\ measured \\ using the 15 \\ item symptom \\ distress scale \\ (SDS-15) \\ Symptom \\ distress as \\ measured \\ using \\ Memorial \\ Symptom \\ Assessment \\ Scale-Short \\ Form (MSAS- \\ SF) \\ Change in \\ daily \\ functional \\ activity and \\ symptoms \\ over three \\ outpatient \\ Significantly lower SDS-15 scores in the \\ intervention group $(P=0.02)$. Intervention was \\ strongest in patients older than $50(P=0.002)$. \\ Significantly improved symptom distress as \\ measured by MSAS-SF in the intervention group \\ (slope estimate, -0.052 [95\% confidence interval, - \\ 0.101 to -0.004$] ; \mathrm{t}=4.42 ; \mathrm{P}=.037$ ). \\ Patients assigned to use the mobile application in \\ combination with physician review had no \\ significant decrease in performance status over \\ three visits. Performance status outcomes were not \\ significantly different that patients who used the \\ application without physician review or a control \\ group that did not use the app.
}

visits

Cancer Support System (CaSSY): webbased intervention with written and audiovisual self-management strategies, a bulletin board, and other resources, visits

Measures of symptom with a care coordinator during a physician's burden appointment every two months, and telephone follow-up every two weeks.
Decreased symptom burden with use of CaSSY system as measured by Functional Assessment of Cancer Therapy - General (FACT-G) $(P<0.05)$
Interleukin (IL)1a, IL-1b, IL-6, and IL-8 levels, Natural Killer (NK) cell numbers
Reductions were noted in IL- 6 , IL-1 $\beta$, IL-1a, and IL8 , and increase in NK cell numbers were observed but were not statistically significant

TABLE 1: Prospective randomized trials of remote patient monitoring and electronic patientreported outcomes (ePRO) in oncology

A similar PRO-based system was tested in the setting of follow-up care for lung cancer. Denis et al. randomized patients with stage IIA or higher lung cancer within three months of previous treatment to either usual care or symptom monitoring using the Sentinel PRO system which involved weekly questionnaires covering 13 symptoms and subsequent automated alerts to the care team for predetermined thresholds in symptom severity or symptom worsening [11]. A total of 133 patients were enrolled from five treatment centers in France; patients with metastatic disease on non-cytotoxic therapy such as tyrosine kinase inhibitors, immunotherapy or antiangiogenic therapy were eligible. The primary endpoint was overall survival. Sixty-three percent had stage IV disease and $17 \%$ had a diagnosis of small cell lung cancer. Ten out of 34 surviving patients in the control group were eligible for crossover into the PRO arm. After two years of follow-up, median survival was longer in the PRO group (22.5 months vs. 14.9 months, HR 0.59 [95\% CI, 0.37-0.96]; $\mathrm{P}=.03$ ) with similar results reported after censoring for crossover. Performance status at time of relapse was 0 or 1 in $75.9 \%$ of the patients in the PRO arm vs only $32.5 \%$ in the control arm. First relapses were detected outside of scheduled visits to the oncologist $72.4 \%$ of the time in the PRO group versus $32.5 \%$ in the control group $(\mathrm{p}<0.001)$. A pre-specified secondary analysis of cost-effectiveness reported by Lizée et al., demonstrated a €362 reduction in annual surveillance costs in the PRO arm (€941 vs. €1304) [12]. 
One of the earliest uses of patient-driven technology to monitor outcomes was the Cancer Care Monitor used by the West Clinic, Memphis, TN, in 2003 [27]. Prior to each scheduled oncology visit, patients would report their symptoms on computers and later digital tablets (Patient Care Monitoring) [28]. This validated survey was used to support a web and mobile-based application prospectively applied to postmenopausal women starting new anti-hormonal therapy to assess whether this tool would improve symptom burden and medication adherence [29]. Of significance, this application was able to increase medication adherence at eight weeks, when complimented with weekly reminders (100\% vs $75 \%$, p < 0.05$)$.

Additional ongoing prospective randomized trials evaluating remote patient monitoring and patient reported outcomes in oncology are summarized in Table 2. In the United States, the Symptom Management Implementation of Patient Reported Outcomes in Oncology (SIMPRO) study aims to enroll 18,000 patients with thoracic, gastrointestinal, and gynecologic malignancies. Patients randomized to the intervention arm will enter symptom data into the mobile electronic symptom management system (eSyM). The primary outcome is 30-day emergency department treat and release rate as measured through medical record abstraction [30]. An additional ongoing US study, the THRIVE study, is a prospective, randomized trial evaluating a web-enabled application to improve adherence to hormonal therapy in women with breast cancer. The study will randomize 300 patients into three separate arms: 1 . a group that receives weekly reminders through the application, 2 . a group that receives weekly reminders and tailored feedback, and a usual care group. The primary endpoint is medication adherence as determined using an electronic pillbox [31]. 


\section{Cureus}

\begin{tabular}{|c|c|c|c|}
\hline Study & Patient population & Intervention & Primary outcome measures \\
\hline $\begin{array}{l}\text { The electronic } \\
\text { Symptom Management } \\
\text { using the Advanced } \\
\text { Symptom Management } \\
\text { System (ASyMS) } \\
\text { Remote Technology } \\
\text { (eSMART) [32] }\end{array}$ & $\begin{array}{l}1108 \text { adult patients } \\
\text { undergoing chemotherapy for } \\
\text { breast, colorectal, or } \\
\text { hematologic cancers in five } \\
\text { European countries }\end{array}$ & $\begin{array}{l}\text { Electronic symptom } \\
\text { reporting using the } \\
\text { electronic Symptom } \\
\text { Management using the } \\
\text { Advanced Symptom } \\
\text { Management System } \\
\text { (ASyMS) }\end{array}$ & $\begin{array}{l}\text { Measurement of symptom burden, with secondary } \\
\text { outcomes including quality of life, supportive care } \\
\text { needs, anxiety, self-care self-efficacy, work limitations, } \\
\text { cost effectiveness, and changes in clinical practice in } \\
\text { response to PRO data }\end{array}$ \\
\hline $\begin{array}{l}\text { Patient Remote } \\
\text { Intervention and } \\
\text { Symptom Management } \\
\text { System (PRISMS) [33] }\end{array}$ & $\begin{array}{l}222 \text { adult patients undergoing } \\
\text { chemotherapy for chronic } \\
\text { lymphocytic leukemia (CLL), } \\
\text { Hodgkin's lymphoma, and } \\
\text { non-Hodgkin's lymphoma } \\
\text { (NHL) in two Australian } \\
\text { hospitals }\end{array}$ & $\begin{array}{l}\text { Symptom reporting via a } \\
\text { computer tablet-based } \\
\text { software system that } \\
\text { prompts patients to enter } \\
\text { twice daily data regarding } \\
\text { physical and emotional } \\
\text { symptoms }\end{array}$ & $\begin{array}{l}\text { Symptom burden due to nausea, mucositis, } \\
\text { constipation, and fatigue }\end{array}$ \\
\hline $\begin{array}{l}\text { The HOPE Trial: } \\
\text { Helping Our Patients } \\
\text { Excel [34] }\end{array}$ & $\begin{array}{l}110 \text { adult patients with } \\
\text { recurrent, incurable } \\
\text { gynecologic malignancies }\end{array}$ & $\begin{array}{l}\text { Combined PRO mobile } \\
\text { application and wearable } \\
\text { activity tracker }\end{array}$ & $\begin{array}{l}\text { Feasibility and acceptability of the HOPE app and the } \\
\text { wearable accelerometers Comparison of two wearable } \\
\text { accelerometers (Fitbit Zip and Fitbit Charge HR) for use } \\
\text { in pilot RCT. Change from baseline in health-related } \\
\text { quality of life (comparing patient-reported baseline and } \\
\text { post-baseline EuroQoL EQ-5D). }\end{array}$ \\
\hline $\begin{array}{l}\text { Home Telemonitoring } \\
\text { for Patients With Lung } \\
\text { Cancer (HTPLC) [35] }\end{array}$ & $\begin{array}{l}70 \text { adult patients admitted to } \\
\text { the hospital for lung cancer as } \\
\text { primary or secondary } \\
\text { diagnosis }\end{array}$ & $\begin{array}{l}\text { Honeywell HomMed } \\
\text { Genesis }{ }^{\mathrm{M}} \text { DM Remote } \\
\text { Patient Care Monitor }\end{array}$ & $\begin{array}{l}\text { Changes in temperature, pulse rate, blood pressure, } \\
\text { SpO2 and weight are measured by telemonitor daily } \\
\text { over } 14 \text { days after hospital discharge }\end{array}$ \\
\hline $\begin{array}{l}\text { Self-monitoring and } \\
\text { Reminder Texts to } \\
\text { Increase Physical } \\
\text { Activity After Cancer II } \\
\text { (SmartPacell) [36] }\end{array}$ & $\begin{array}{l}44 \text { adult patients with colon or } \\
\text { rectal cancer expected to } \\
\text { receive at least } 12 \text { weeks of } \\
\text { chemotherapy }\end{array}$ & $\begin{array}{l}\text { Activity tracking using } \\
\text { FitBit }^{\mathrm{TM}}\end{array}$ & $\begin{array}{l}\text { Fitbit } \mathrm{TM}^{\mathrm{M}} \text { wear time Acceptability of the intervention Text } \\
\text { message response rate }\end{array}$ \\
\hline $\begin{array}{l}\text { Symptom Management } \\
\text { Implementation of } \\
\text { Patient Reported } \\
\text { Outcomes in Oncology } \\
\text { (SIMPRO) [30] }\end{array}$ & $\begin{array}{l}18,000 \text { adult patients with } \\
\text { thoracic, gastrointestinal, or } \\
\text { gynecologic malignancies } \\
\text { following surgery or } \\
\text { scheduled to start a new } \\
\text { treatment plan. }\end{array}$ & $\begin{array}{l}\text { Mobile electronic symptom } \\
\text { management system } \\
\text { (eSyM) }\end{array}$ & $\begin{array}{l}\text { Emergency Department - Treat and Release (EDTR) } \\
\text { Rate at } 30 \text { days }\end{array}$ \\
\hline THRIVE Study [29] & $\begin{array}{l}300 \text { adult women undergoing } \\
\text { hormonal therapy for breast } \\
\text { cancer }\end{array}$ & $\begin{array}{l}\text { Web-enabled application to } \\
\text { improve adherence to } \\
\text { hormonal therapy }\end{array}$ & $\begin{array}{l}\text { Adherence to hormonal therapy as determined using an } \\
\text { electronic pillbox. }\end{array}$ \\
\hline eRAPID [37] & $\begin{array}{l}504 \text { adult patients receiving } \\
\text { chemotherapy for breast, } \\
\text { colorectal, or gynecologic } \\
\text { cancer }\end{array}$ & $\begin{array}{l}\text { Electronic patient self- } \\
\text { reporting of adverse } \\
\text { events: patient information } \\
\text { and advice (eRAPID). }\end{array}$ & luality of life as measured using FACT-G \\
\hline $\begin{array}{l}\text { Karolinska mHealth } \\
\text { Study [38] }\end{array}$ & $\begin{array}{l}150 \text { prostate cancer patients } \\
\text { scheduled for definitive } \\
\text { radiation therapy and } 150 \\
\text { breast cancer patients } \\
\text { scheduled for neoadjuvant } \\
\text { chemotherapy }\end{array}$ & $\begin{array}{l}\text { Daily symptom reporting } \\
\text { using a mobile platform on } \\
\text { either mobile phone or } \\
\text { tablet computer. }\end{array}$ & $\begin{array}{l}\text { Symptom burden, quality of life, health literacy, disease } \\
\text { progress, and health care costs }\end{array}$ \\
\hline
\end{tabular}


the indications and benefits of PRO-based systems. The electronic Symptom Management using the Advanced Symptom Management System (ASyMS) Remote Technology (eSMART) study aims to enroll 1108 patients from five European countries undergoing first-line chemotherapy for breast, colorectal, or hematologic cancer [32]. The primary outcome is measurement of symptom burden, with secondary outcomes including quality of life, supportive care needs, anxiety, self-care self-efficacy, work limitations, cost effectiveness, and changes in clinical practice in response to PRO data. A similar study is being undertaken in Australia for hematologic malignancies utilizing the Patient Remote Intervention and Symptom Management System (PRISMS), a computer tablet-based software system that prompts patients to enter twice daily data regarding physical and emotional symptoms [33]. The PRISMS study aims to enroll 222 patients undergoing chemotherapy for chronic lymphocytic leukemia (CLL), Hodgkin's lymphoma, and nonHodgkin's lymphoma (NHL) in two Australian hospitals. The primary outcome focuses on symptom burden due to nausea, mucositis, constipation, and fatigue.

\section{Physiologic monitoring in oncology}

Ubiquitous smartphones and miniaturization of sensor and communication technology has led to enormous data gathering enterprises in consumer and healthcare markets. Smartphone accelerometers, GPS tracking, and high-resolution cameras are critical to fitness and wellness applications but also as diagnostic tools such as remote skin cancer detection. These same devices when combined with subjective PRO feedback can be used to guide patient care or provide prognostic data.

Performance status (PS), commonly measured using the Karnofsky or Eastern Cooperative Oncology Group (ECOG) PS scale, is one of the strongest predictors of cancer survival outcomes and risk of treatment toxicity. Patients with a compromised PS have higher risks of morbidity and mortality, but current clinical PS assessments, despite their critical role in clinical trials, are limited by subjectivity and high rates of interobserver variability [39-41]. Many consumer and medical wearables contain three-axis accelerometers and three-axis gyroscopes, providing continuous readings of individual movement which holds significant promise as a means of overcoming the current limitations of physician identified performance status. Gresham et al. evaluated the feasibility of using activity data from FitBit Charge HR ${ }^{\circledR}$ wearable devices as a surrogate for PS in 37 patients with cancer, 92\% of whom had stage IV disease [42]. They reported high correlations between average daily step counts and ECOG-PS $(r=0.63)$; each increase in daily step count by 1000 was associated with a significant decrease in adverse events, hospitalization, and hazard for death. Strong correlation was also reported between these activity metrics and PRO data. Subsequent systematic review of published studies evaluating the use of activity tracking in cancer care identified 41 trials including active cancer patients and those undergoing follow-up and survivorship care [43]. Most trials included breast cancer patients (65\%) and focused on exercise (54\%) or behavioral (29\%) interventions. Twelve trials evaluated daily step counts, and the reported steps per day were slightly lower in patients on active cancer therapy (2885 to 8300 steps/day) compared to survivors (4660 to 11,000 steps per day). No studies included implantable monitoring devices.

\section{Current technology limitations}

While PRO platforms and wearable technology have potential to improve care, implementation in the clinic faces many challenges. Web-based PRO platforms rely on patient engagement, which can be increasingly problematic in an aging cancer population with less familiarity with technology. Furthermore, waiting for patients to report symptoms lacks a proactive preventative solution.

With regards to wearable technology, most studies demonstrate feasibility, however patient adherence remains a major limitation. Seventeen of the studies included in the Gresham systematic review reported adherence data, but adherence was defined differently in most studies [43]. The most commonly reported adherence metric was three consecutive days of activity tracking (range: 3-7 consecutive days), with a valid wear time as 5 to 10 hours per day. These definitions of adherence leave large gaps in time where no data is gathered or reported, limiting the ability to produce high fidelity analytics and accurate diagnostic tools. Additionally, for cancer patients facing several months of therapy, three to seven consecutive days of activity tracking does not represent reliable monitoring through the duration of treatment and follow-up.

Dreher et al. demonstrated similar adherence limitations in a study of FitBit ${ }^{\circledR}$ use in breast cancer patients, stating, "Adherence to wearing the Fitbit was low, with $16.9 \%$ of patients never syncing their device." For patients who did sync their devices, the median number of valid activity tracking days (defined as > 10 hours of use) during the 9 -month duration of the study was only $44.5 \%$ (median $=39.6 \%$, range $0 \%-100 \%$ ) [44]. Even the much-publicized Apple Watch ${ }^{\circledR}$ atrial fibrillation study, a population consisting of Apple Watch ${ }^{\circledR}$ owners, showed poor adherence with only $21 \%$ of those who received an irregular pulse notification initiating the first indicated visit [45]. The studies utilizing wearable technology in oncology care demonstrate the importance of objective data gathering, but also highlight the limitations of systems that rely on patient adherence. Alternatively, the studies involving cardiac referenced in the introduction show significant benefits associated with the reliable and continuous monitoring from implantable sensor technology, including disease control, survival, and economic endpoints.

\section{Future directions}




\section{Cureus}

Representative ongoing early phase or pilot studies evaluating emerging digital technology in cancer care are summarized in Table 3. Emerging research shows benefits in outcomes and costs of cancer care through use of remote monitoring technology especially electronic patient reported outcomes (ePRO). However, broad clinical adoption has been limited by a lack of commercially available oncology specific solutions, concerns about reimbursement, and limitations associated with low patient adherence. Several companies offer products addressing this need including software and mobile technology startup companies such as Noona (acquired by Varian Medical Systems, Palo Alto, CA), Kaiku Health, and Navigating Cancer, all offering ePRO solutions. Oleena provides a physician prescribed digital therapeutic that integrates ePRO features for oncology. Vital Connect, VivaLnk, and Current Health integrate physiologic data from wearable and in-home connected devices for oncology and other acute or chronic diseases (Table 4).

\begin{tabular}{|c|c|c|c|c|}
\hline Sponsor & Diagnoses & $\begin{array}{l}\text { Estimated } \\
\text { Enrollment }\end{array}$ & Primary Outcome & Technology and Data Gathered \\
\hline $\begin{array}{l}\text { Massachusetts } \\
\text { General } \\
\text { Hospital }\end{array}$ & $\begin{array}{l}\text { Gastrointestinal } \\
\text { Malignancies }\end{array}$ & 75 patients & $\begin{array}{l}\text { Feasibility of remote electronic patient } \\
\text { monitoring defined as participant use of } \\
\text { monitoring device at least } 50 \% \text { of the time } \\
\text { within two weeks of enrollment }\end{array}$ & $\begin{array}{l}\text { Wearable vital sign monitor that } \\
\text { communicates with patients' mobile } \\
\text { device, data presented on care team } \\
\text { dashboard }\end{array}$ \\
\hline $\begin{array}{l}\text { Gaido }{ }^{\circledR} \text { and } \\
\text { the Guthrie } \\
\text { Clinic }\end{array}$ & $\begin{array}{l}\text { Adult cancer patients } \\
\text { receiving chemotherapy }\end{array}$ & 30 patients & $\begin{array}{l}\text { Feasibility of Gaido intervention with analyses } \\
\text { of utilization, wear time, and completion of PRO } \\
\text { over three weeks of enrollment }\end{array}$ & $\begin{array}{l}\text { Gaido } ₫ \text { system with Biovotion } \\
\text { Everion }{ }^{\circledR} \text { wearable device for } \\
\text { remote vital sign collection, manual } \\
\text { entry of temperature and blood } \\
\text { pressure }\end{array}$ \\
\hline $\begin{array}{l}\text { Sidney Kimmel } \\
\text { Cancer Center } \\
\text { at Thomas } \\
\text { Jefferson } \\
\text { University }\end{array}$ & $\begin{array}{l}\text { patients undergoing } \\
\text { radiotherapy or } \\
\text { chemoradiotherapy }\end{array}$ & 41 patients & $\begin{array}{l}\text { Percentage of time using wearable technology, } \\
\text { compliance defined as wearing device } 19 / 24 \\
\text { hours ( } 80 \% \text { daily use) for } 70 \% \text { of the days } \\
\text { under treatment }\end{array}$ & FitBit $₫$ Charge 3 and online PRO \\
\hline $\begin{array}{l}\text { Augusta } \\
\text { University }\end{array}$ & $\begin{array}{l}\text { Adult patients with acute } \\
\text { myeloid leukemia (AML) } \\
\text { and are candidate for } \\
\text { high-dose cytarabine }\end{array}$ & 30 patients & $\begin{array}{l}\text { Change in number of ICU admissions and } \\
\text { incidence of sepsis compared with historical } \\
\text { cohort }\end{array}$ & $\begin{array}{l}\text { Continuous remote temperature } \\
\text { monitoring device }\end{array}$ \\
\hline $\begin{array}{l}\text { Duke } \\
\text { University }\end{array}$ & $\begin{array}{l}\text { Adult patients with } \\
\text { metastatic cancer }\end{array}$ & $\begin{array}{l}100 \\
\text { patients }\end{array}$ & Subject participation over 12 months & Noona $\otimes^{\circledR}$ ePRO system \\
\hline AstraZeneca & $\begin{array}{l}\text { Unresectable Stage III } \\
\text { non-small cell lung } \\
\text { cancer }\end{array}$ & 75 patients & $\begin{array}{l}\text { Total number of confirmed pneumonitis cases } \\
\text { by grade \& number of cases identified early } \\
\text { through mobile technology in patients receiving } \\
\text { darvalumab }\end{array}$ & $\begin{array}{l}\text { Multiparametric mobile technology } \\
\text { collecting patient reported } \\
\text { outcomes, vital signs, and } \\
\text { respiratory function including a } \\
\text { spirometer, an armband, and a } \\
\text { tablet to collect data. }\end{array}$ \\
\hline $\begin{array}{l}\text { University of } \\
\text { Michigan }\end{array}$ & $\begin{array}{l}\text { Pediatric patients (age } 5 \\
\text { or older) eligible for CAR } \\
\text { T-cell therapy }\end{array}$ & $\begin{array}{l}30 \text { patients } \\
\text { and } 30 \\
\text { caregivers }\end{array}$ & $\begin{array}{l}\text { Percentage of caregivers that log on to BMT } \\
\text { Roadmap at least once per day for four of } \\
\text { seven days while patient is in the hospital and } \\
\text { feasibility of implementing the full system } \\
\text { including activity tracking in pediatric } \\
\text { population }\end{array}$ & $\begin{array}{l}\text { Mobile tablet for utilization of the } \\
\text { BMT Roadmap information system } \\
\text { and wearable activity tracker }\end{array}$ \\
\hline $\begin{array}{l}\text { Washıngton } \\
\text { University } \\
\text { School of } \\
\text { Medicine }\end{array}$ & $\begin{array}{l}\text { Non-metastatic } \\
\text { malignancy of the thorax } \\
\text { and planning treatment } \\
\text { with radiotherapy with or } \\
\text { without chemotherapy }\end{array}$ & 50 patients & $\begin{array}{l}\text { Percentage of invited symptom reports } \\
\text { completed and percentage of questions } \\
\text { completed within each invited symptom report } \\
\text { [treatment through } 90 \text { days of follow-up } \\
\text { (estimated to be five months)] }\end{array}$ & Noona $\otimes^{\circledR}$ ePRO system \\
\hline
\end{tabular}

TABLE 3: Select ongoing early phase studies of emerging technology for remote patient monitoring and ePRO for oncology

ePRO: electronic patient-reported outcome 


\section{Cureus}

\begin{tabular}{|c|c|c|c|}
\hline Company & Stage & Target Market & Technology \\
\hline Apple & Commercial & Consumer wellness & Wearable smart watch (Apple Watch $\Theta$ ) and mobile phone (iPhone $\mathrm{T}^{\mathrm{TM}}$ ) \\
\hline CareVive & Commercial & Oncology practices & $\begin{array}{l}\text { Treatment planning and clinical trial matching, ePRO reporting, and survivorship } \\
\text { care planning }\end{array}$ \\
\hline $\begin{array}{l}\text { Current } \\
\text { Health }\end{array}$ & Commercial & $\begin{array}{l}\text { Hospitals and } \\
\text { oncology practices }\end{array}$ & $\begin{array}{l}\text { Wearable device for vital sign monitoring and data analytics for early detection of } \\
\text { complications }\end{array}$ \\
\hline FitBit & Commercial & Consumer wellness & Wearable activity tracker and smart watch (Versa ${ }^{\mathrm{TM}}$ and Charge $^{\mathrm{TM}}$ ) \\
\hline $\begin{array}{l}\text { Kaiku } \\
\text { Health }\end{array}$ & Commercial & $\begin{array}{l}\text { Oncology practices } \\
\text { (Europe) }\end{array}$ & Mobile PRU reporting and data analytics \\
\hline $\begin{array}{l}\text { Navigating } \\
\text { Cancer }\end{array}$ & Commercial & Oncology practices & Digital patient care management, remote PRO monitoring, and patient engagement \\
\hline Noona & $\begin{array}{l}\text { Commerclal and } \\
\text { clinical trials }\end{array}$ & Oncology practices & lobile PRU reporting plattorm \\
\hline Oleena & Commercial & Oncology practices & $\begin{array}{l}\text { Digital therapeutic/prescribed mobile app with ePRO reporting and symptom } \\
\text { management }\end{array}$ \\
\hline Oncodisc & Preclinical & $\begin{array}{l}\text { Uncology practices } \\
\text { and hospitals }\end{array}$ & $\begin{array}{l}\text { Remote oncology care plattorm with mobile ePRO and vital sign data from } \\
\text { intelligent implantable vascular access device }\end{array}$ \\
\hline Connect & Commercial & Hospitals & Wearable patch and data reporting plattorm (VitalPatch ${ }^{\mathrm{m}}$ ) \\
\hline VivaLnk & Commercial & Healthcare providers & earable vital sign monitoring patch and reporting dashboard \\
\hline
\end{tabular}

\section{TABLE 4: Select companies commercializing technology for remote patient monitoring or ePRO in}

oncology

ePRO: electronic patient-reported outcome

A preferred solution would securely and reliably gather digital physiologic data without requiring patient activation, much like pulmonary artery pressure monitors and implantable loop recorders in cardiology. Additionally, such a system would contain mobile patient engagement and ePRO tools that could be tied to existing reimbursement framework facilitating rapid adoption. Powerful analytic tools including machine learning and artificial intelligence could then be applied to identify early signs of common complications and provide individual patient health and risk profiles, allowing oncologists to make more informed and personalized treatment recommendations. The use of an implantable device in oncology has already been explored, as oncologic cardiologists at MD Anderson Cancer Center have utilized implantable loop recorders and CardioMEMS ${ }^{\circledR}$ to monitor patients at high risk of complications from cardiotoxic systemic therapy, but data regarding safety and efficacy is lacking [46]. To our knowledge, Oncodisc, a San Francisco-based medical technology start-up, is the only company developing implantable monitoring technology and mobile ePRO solutions for oncology. The Oncodisc device, an intelligent implantable vascular access port, takes advantage of existing oncology workflow and a common minimally invasive procedure with established reimbursement.

\section{Conclusions}

The current Covid-19 pandemic has highlighted the need for reliable connected systems to facilitate home care while reducing hospitalizations and clinic visits, especially in immunocompromised cancer patients. Early studies show significant benefits to PRO-based systems, including lower costs and prolongation of survival. Further advances in sensor technology and mobile communications hold great promise for improving cancer outcomes while at the same time reducing costs. However, widespread adoption has been hampered by a lack of commercially available solutions. To that end, implantable physiologic sensor systems and associated data analytic tools, akin to those used in cardiovascular care, should be researched for oncology.

\section{Additional Information}

\section{Disclosures}

Conflicts of interest: In compliance with the ICMJE uniform disclosure form, all authors declare the 
following: Payment/services info: All authors have declared that no financial support was received from any organization for the submitted work. Financial relationships: James D. Mitchell, Gregory A. Vidal, Sumit A. Shah, Bradley McGregor, Andrew E. Hendifar declare(s) stock/stock options from Oncodisc, Inc. Dr. Mitchell is founder and CEO of Oncodisc, Inc. Drs. McGregor, Shah, Hendifar, and Vidal are members of the Oncodisc scientific advisory board. Intellectual property info: Dr. Mitchell is a named inventor on six patent applications related to this work. Other relationships: All authors have declared that there are no other relationships or activities that could appear to have influenced the submitted work.

\section{References}

1. Cancer stat facts: cancer of any site . (2020). Accessed: July 1, 2020:

https://seer.cancer.gov/statfacts/html/all.html.

2. Prince RM, Atenafu EG, Krzyzanowska MK: Hospitalizations during systemic therapy for metastatic lung cancer: a systematic review of real world vs clinical trial outcomes. JAMA Oncol. 2015, 1:1333-1339. 10.1001/jamaoncol.2015.3440

3. Lipitz-Snyderman A, Klotz A, Atoria CL, Martin S, Groeger J: Impact of observation status on hospital use for patients with cancer. J Oncol Pract. 2015, 11:73-77. 10.1200/JOP.2014.001248

4. Prince RM, Powis M, Zer A, Atenafu EG, Krzyzanowska MK: Hospitalisations and emergency department visits in cancer patients receiving systemic therapy: systematic review and meta-analysis. Eur J Cancer Care (Engl). 2019, 28:12909. 10.1111/ecc.12909

5. Numico G, Cristofano A, Mozzicafreddo A, et al.: Hospital admission of cancer patients: avoidable practice or necessary care?. PLoS One. 2015, 10:0120827. 10.1371/journal.pone.0120827

6. Kuderer NM, Dale DC, Crawford J, Cosler LE, Lyman GH: Mortality, morbidity, and cost associated with febrile neutropenia in adult cancer patients. Cancer. 2006, 106:2258-2266. 10.1002/cncr.21847

7. Jairam V, Lee V, Park HS, et al.: Treatment-related complications of systemic therapy and radiotherapy . JAMA Oncol. 2019, 5:1028-1035. 10.1001/jamaoncol.2019.0086

8. Liao Y, Thompson C, Peterson S, Mandrola J, Beg MS: The future of wearable technologies and remote monitoring in health care. Am Soc Clin Oncol Educ Book. 2019, 39:115-121. 10.1200/EDBK_238919

9. Abraham WT, Stevenson LW, Bourge RC, Lindenfeld JA, Bauman JG, Adamson PB: Sustained efficacy of pulmonary artery pressure to guide adjustment of chronic heart failure therapy: complete follow-up results from the CHAMPION randomised trial. Lancet. 2016, 387:453-461. 10.1016/S0140-6736(15)00723-0

10. Sanna T, Diener HC, Passman RS, et al.: Cryptogenic stroke and underlying atrial fibrillation. N Engl J Med. 2014, 370:2478-2486. 10.1056/NEJMoa1313600

11. Denis F, Basch E, Septans AL, Bennouna J, Urban T, Dueck AC, Letellier C: Two-year survival comparing web-based symptom monitoring vs routine surveillance following treatment for lung cancer. JAMA. 2019, 321:306-307. 10.1001/jama.2018.18085

12. Lizée $\mathrm{T}$, Basch $\mathrm{E}$, Trémolières $\mathrm{P}$, et al.: Cost-effectiveness of web-based patient-reported outcome surveillance in patients with lung cancer. J Thorac Oncol. 2019, 14:1012-1020. 10.1016/j.jtho.2019.02.005

13. Basch E, Deal AM, Dueck AC, Scher HI, Kris MG, Hudis C, Schrag D: Overall survival results of a trial assessing patient-reported outcomes for symptom monitoring during routine cancer treatment. JAMA. 2017, 318:197-198. 10.1001/jama.2017.7156

14. Basch E, Deal AM, Kris MG, et al.: Symptom monitoring with patient-reported outcomes during routine cancer treatment: a randomized controlled trial. J Clin Oncol. 2016, 34:557-565. 10.1200/JCO.2015.63.0830

15. Harky A, Chiu CM, Yau THL, Lai SHD: Cancer patient care during COVID-19. Cancer Cell. 2020, 37:749-750. 10.1016/j.ccell.2020.05.006

16. Ueda M, Martins R, Hendrie PC, et al.: Managing cancer care during the COVID-19 pandemic: agility and collaboration toward a common goal. J Natl Compr Canc Netw. 2020, 18:4. 10.6004/jnccn.2020.7560

17. Coronavirus: what people with cancer should know. (2020). Accessed: July 5, 2020: https://www.cancer.gov/contact/emergency-preparedness/coronavirus.

18. Mooney KH, Beck SL, Wong B, Dunson W, Wujcik D, Whisenant M, Donaldson G: Automated home monitoring and management of patient-reported symptoms during chemotherapy: results of the symptom care at home RCT. Cancer Med. 2017, 6:537-546. 10.1002/cam4.1002

19. Berry DL, Blumenstein BA, Halpenny B, et al.: Enhancing patient-provider communication with the electronic self-report assessment for cancer: a randomized trial. J Clin Oncol. 2011, 29:1029-1035. 10.1200/JCO.2010.30.3909

20. Cleeland CS, Wang XS, Shi Q, et al.: Automated symptom alerts reduce postoperative symptom severity after cancer surgery: a randomized controlled clinical trial. J Clin Oncol. 2011, 29:994-1000. 10.1200/JCO.2010.29.8315

21. Kuo JC, Graham DM, Salvarrey A, et al.: A randomized trial of the electronic Lung Cancer Symptom Scale for quality-of-life assessment in patients with advanced non-small-cell lung cancer. Curr Oncol. 2020, 27:156162. $10.3747 / \mathrm{co} .27 .5651$

22. Strasser F, Blum D, von Moos R, et al.: The effect of real-time electronic monitoring of patient-reported symptoms and clinical syndromes in outpatient workflow of medical oncologists: E-MOSAIC, a multicenter cluster-randomized phase III study (SAKK 95/06). Ann Oncol. 2016, 27:324-332. 10.1093/annonc/mdv576

23. Berry DL, Hong F, Halpenny B, et al.: Electronic self-report assessment for cancer and self-care support: results of a multicenter randomized trial. J Clin Oncol. 2014, 32:199-205. 10.1200/JCO.2013.48.6662

24. Ruland CM, Andersen T, Jeneson A, et al.: Effects of an internet support system to assist cancer patients in reducing symptom distress: a randomized controlled trial. Cancer Nurs. 2013, 36:6-17. 10.1097/NCC.0b013e31824d90d4

25. Egbring M, Far E, Roos M, Dietrich M, Brauchbar M, Kullak-Ublick GA, Trojan A: A mobile app to stabilize daily functional activity of breast cancer patients in collaboration with the physician: a randomized controlled clinical trial. J Med Internet Res. 2016, 18:238. 10.2196/jmir.6414

26. Steel JL, Geller DA, Kim KH, et al.: Web-based collaborative care intervention to manage cancer-related 
symptoms in the palliative care setting. Cancer. 2016, 122:1270-1282. 10.1002/cncr.29906

27. Fortner B, Baldwin S, Schwartzberg L, Houts AC: Validation of the cancer care monitor items for physical symptoms and treatment side effects using expert oncology nurse evaluation. J Pain Symptom Manage. 2006, 31:207-214. 10.1016/j.jpainsymman.2005.07.009

28. Olsen JP, Baldwin S, Houts AC: The patient care monitor-neutropenia index: development, reliability, and validity of a measure for chemotherapy-induced neutropenia. Oncol Nurs Forum. 2011, 38:360-367. 10.1188/11.ONF.360-367

29. Graetz I, McKillop CN, Stepanski E, Vidal GA, Anderson JN, Schwartzberg LS: Use of a web-based app to improve breast cancer symptom management and adherence for aromatase inhibitors: a randomized controlled feasibility trial. J Cancer Surviv. 2018, 12:431-440. 10.1007/s11764-018-0682-z

30. Symptom management implementation of patient reported outcomes in oncology (SIMPRO) . (2020). Accessed: August 1, 2020: https://clinicaltrials.gov/ct2/show/NCT03850912.

31. Paladino AJ, Anderson JN, Krukowski RA, et al.: THRIVE study protocol: a randomized controlled trial evaluating a web-based app and tailored messages to improve adherence to adjuvant endocrine therapy among women with breast cancer. BMC Health Serv Res. 2019, 19:977. 10.1186/s12913-019-4588-x

32. Maguire R, Fox PA, McCann L, et al.: The eSMART study protocol: a randomised controlled trial to evaluate electronic symptom management using the advanced symptom management system (ASyMS) remote technology for patients with cancer. BMJ Open. 2017, 7:e015016. 10.1136/bmjopen-2016-015016

33. Breen S, Ritchie D, Schofield P, et al.: The patient remote intervention and symptom management system (PRISMS) - a Telehealth-mediated intervention enabling real-time monitoring of chemotherapy side-effects in patients with haematological malignancies: study protocol for a randomised controlled trial. Trials. 2015, 16:472. 10.1186/s13063-015-0970-0

34. The HOPE trial: helping our patients excel . (2020). Accessed: August 4, 2020: https://clinicaltrials.gov/ct2/show/NCT03022032.

35. Home telemonitoring for patients with lung cancer (HTPLC) . (2020). Accessed: August 4, 2020: https://clinicaltrials.gov/ct2/show/NCT01670539.

36. Self-monitoring and reminder texts to increase physical activity after cancer II (SmartPaceII) . (2020). Accessed: August 3, 2020: https://clinicaltrials.gov/ct2/show/NCT03524716.

37. Absolom K, Holch P, Warrington L, et al.: Electronic patient self-reporting of adverse-events: patient information and aDvice (eRAPID): a randomised controlled trial in systemic cancer treatment. BMC Cancer. 2017, 17:318. 10.1186/s12885-017-3303-8

38. Langius-Eklöf A, Crafoord MT, Christiansen M, Fjell M, Sundberg K: Effects of an interactive mHealth innovation for early detection of patient-reported symptom distress with focus on participatory care: protocol for a study based on prospective, randomised, controlled trials in patients with prostate and breast cancer. BMC Cancer. 2017, 17:466. 10.1186/s12885-017-3450-y

39. Christakis NA, Lamont EB: Extent and determinants of error in doctors' prognoses in terminally ill patients: prospective cohort study. BMJ. 2000, 320:469-472. 10.1136/bmj.320.7233.469

40. Taylor AE, Olver IN, Sivanthan T, Chi M, Purnell C: Observer error in grading performance status in cancer patients. Support Care Cancer. 1999, 7:332-335. 10.1007/s005200050271

41. Blagden SP, Charman SC, Sharples LD, Magee LR, Gilligan D: Performance status score: do patients and their oncologists agree?. Br J Cancer. 2003, 89:1022-1027. 10.1038/sj.bjc.6601231

42. Gresham G, Hendifar AE, Spiegel B, et al.: Wearable activity monitors to assess performance status and predict clinical outcomes in advanced cancer patients. NPJ Digit Med. 2018, 1:27. 10.1038/s41746-0180032-6

43. Gresham G, Schrack J, Gresham LM, et al.: Wearable activity monitors in oncology trials: current use of an emerging technology. Contemp Clin Trials. 2018, 64:13-21. 10.1016/j.cct.2017.11.002

44. Dreher N, Hadeler EK, Hartman SJ, et al.: Fitbit usage in patients with breast cancer undergoing chemotherapy. Clin Breast Cancer. 2019, 19:443-449. 10.1016/j.clbc.2019.05.005

45. Perez MV, Mahaffey KW, Hedlin H, et al.: Large-scale assessment of a smartwatch to identify atrial fibrillation. N Engl J Med. 2019, 381:1909-1917. 10.1056/NEJMoa1901183

46. Implantable devices track cardiac events in cancer patients . (2020). Accessed: July 1, 2020: https://www.mdanderson.org/publications/cancer-frontline/implantable-devices-track-cardiac-events-incancer-patients..... 